Ssciendo Studia Anglica Posnaniensia 56s1 (2021): 425-450

doi: 10.2478/stap-2021-0008

\title{
SPATIO-TEMPORAL SYSTEMS IN SHAKESPEARE'S DIALOGUES: A CASE FROM JULIUS CAESAR
}

\author{
MINAKO NAKAYASU ${ }^{1}$
}

ABSTRACT

The purpose of this paper is to conduct the first systematic analysis of the spatio-temporal systems in Shakespeare's dialogues along the lines of historical pragmatics and discourse analysis. The text used for analysis is The Riverside Shakespeare edited by Evans (1997).

Language employs spatio-temporal systems by which the speakers judge how distant the situations they wish to express are from their domain. Such relationships of space and time are embodied by spatio-temporal elements such as pronouns, demonstratives, adverbs, tenses, and modals, with a proximal (close) and distal (distant) distinction. These elements can be related to each other to take either a proximal or distal perspective not only in either the spatial or temporal domain, but also in the integrated spatio-temporal domain. The speakers can continue to take the same perspective, or alternate different perspectives, in discourse. However, few studies have attempted such a comprehensive analysis of spatio-temporal systems in the development of English, not to mention in its Early Modern period.

This paper performs both quantitative and qualitative analyses of the spatio-temporal systems in Julius Caesar. First, a quantitative analysis of how frequently each element of space and time is employed shows which perspective, i.e., proximal or distal, is likely to be taken. Second, a qualitative analysis reveals how these elements are related with each other to take either proximal or distal perspective, and how these perspectives change in discourse. In these analyses, the present paper pays attention to the interactions between the interlocutors in order to investigate how these interactions in dialogues impact the selection of elements of space and time.

Keywords: Shakespeare; Julius Caesar; spatio-temporal system; historical pragmatics; discourse analysis; proximal and distal perspectives.

\section{Introduction}

SPATIO-TEMPORAL SYSTEMS are the systems built in language by which the speakers judge how distant the situations they wish to express are from their

1 Hamamatsu University School of Medicine; 1-20-1 Handayama, Higashi-ku, Hamamatsushi, Shizuoka 431-3192 Japan; nakayasu@ hama-med.ac.jp 
domain, i.e., their here and now (Nakayasu 2015; 2017a; 2017b; 2018; 2019). ${ }^{2}$ There are numerous situations (e.g., events and states) unremittingly occurring around them, and they choose some to put into language. In doing so, they continuously judge whether these situations are situated close to (PROXIMAL) or distant from (DISTAL) in relation to their domain. In the following example (1) taken from Shakespeare's Julius Caesar, the speaker Antony addresses the citizens of Rome in a public speech, trying to persuade them against the conspirators, Brutus in particular, who have assassinated Caesar:

(1) Ant. [...] Did this in Caesar seem ambitious?

When that the poor have cried, Caesar hath wept;

Ambition should be made of sterner stuff:

Yet Brutus says he was ambitious,

And Brutus is an honorable man.

You all did see that on the Lupercal

I thrice presented him a kingly crown,

Which he did thrice refuse. Was this ambition?

Yet Brutus says he was ambitious,

And sure he is an honorable man.

$(\mathrm{JC} 3.2 .90-99)^{3}$

He employs such elements as pronouns, demonstratives, tense forms, and modals, both proximal and distal, which are considered part of the spatio-temporal systems. These elements are interrelated to each other to evoke either a proximal or distal perspective not only in the spatial or temporal domain, but also in the integrated spatio-temporal domain. The speaker can then continue to take the same perspective, or alternate different perspectives, in discourse.

Only a limited number of studies have previously attempted to integrate both spatial and temporal domains. Traugott $(1974 ; 1978)$ is the first researcher to employ the term spatio-temporal. Among other studies which are related to both domains, we can find Fries (1994) on text deixis in Early Modern English, Taavitsainen (1999) on personality and style of affect, and Nagucka (2000) on spatial and temporal meanings of before. These studies are pioneering in the sense that they attempted a merger of space and time; however, they remain a long way from a systematic analysis of the spatio-temporal systems. In more recent papers, Nakayasu $(2015 ; 2017 \mathrm{a} ; 2017 \mathrm{~b} ; 2018$; 2019) conducted systematic analyses of the spatio-temporal systems employed in both Chaucer and Paston letters. She examined which perspective, proximal or distal, was likely to be taken in these

Or the deictic centre (Yule 1996: 9).

The numbers in the source represent the act, the scene and the line(s), respectively. 
corpora, observed how elements of space and time were coordinated to evoke either proximal or distal perspective, and examined how these perspectives changed in discourse. These studies, however, are all concerned with Middle English, and therefore the analysis of materials taken from a different period of time, Early Modern English for example, is needed in order to shed light on the historical development of the systems.

The present paper conducts the first systematic analysis of the spatio-temporal systems in Shakespeare's dialogues (Early Modern English) against the background of historical pragmatics and discourse analysis (Taavitsainen \& Jucker 2010; 2015). The corpus for this study, The tragedy of Julius Caesar, is taken from The Riverside Shakespeare (Evans 1997), consisting of 20,710 words. Since dramatic dialogue has an interactive nature (Magnusson 1999: 4; 2001: 130), the present paper also examines how interactions between interlocutors impact the selection of spatio-temporal elements in Shakespeare's dialogues. ${ }^{4}$ Limiting the scope of the corpus makes it possible to run a detailed analysis of the systems, both quantitative and qualitative. The discussion sets out by establishing the definition of spatio-temporal systems in Section 2. The third section will carry out a quantitative analysis to show which perspective, proximal or distal, is likely to be taken. Section 4 will then conduct a qualitative analysis of the systems in discourse to describe how these elements are coordinated to take a proximal or distal perspective and how these perspectives shift in discourse. The final section is my conclusion.

\section{Spatio-temporal systems}

Before embarking on the quantitative and qualitative analysis of the spatiotemporal systems in Julius Caesar, this section will establish the definition of spatio-temporal systems based on Nakayasu (2018).

First and foremost, spatio-temporal systems are deictic in nature (e.g., Bühler 1934; Fillmore 1975 [1997]). When using language, speakers continuously choose some situations to put into language and judge how distant these situations are from their own domain. Those close to this domain are referred to proximal, while those distant from it are distal (e.g., Levinson 1983; Diessel 1999; Huang 2014). In addition to prototypical distance (spatial and temporal distance), distal

4 Shakespeare's plays are written in the form of dialogue, with no narrator, and interrupted by few stage directions (Walker 2007: 183; Morgan 2019: 2). More precisely, discourse in Shakespeare's plays may be classified into two kinds: discourse with a certain kind of addressee (i.e., dialogue and speech) and discourse without such an addressee (i.e., monologue) (Nakayasu 2009: 95-96). 
elements may express metaphorical and hypothetical distances (OakeshottTaylor 1984; Nakayasu 2009).

Secondly, spatio-temporal systems embrace a variety of elements that refer to space and time, as is shown in Table $1:^{5}$

Table 1. Elements of space and time

\begin{tabular}{|c|c|c|}
\hline Category & Proximal & Distal \\
\hline \multirow[t]{2}{*}{ Pronoun } & 1st person $(I, w e)$ & $\begin{array}{l}\text { 3rd person (he, she, it, } \\
\text { they) }\end{array}$ \\
\hline & \multicolumn{2}{|c|}{ Medial: 2nd person (thou, you) } \\
\hline Demonstrative & this, these & that, those \\
\hline Adverb (spatial) & here & there \\
\hline Tense form & present & past, past perfect \\
\hline \multirow[t]{6}{*}{ Modal } & shall & should \\
\hline & will & would \\
\hline & can & could \\
\hline & may & might \\
\hline & must & \\
\hline & $' l l$ & \\
\hline Adverb (temporal) & now & then \\
\hline
\end{tabular}

Elements which typically express spatial relations are pronouns, demonstratives, and spatial adverbs. While the latter two categories exhibit a dichotomy of proximal and distal, the former indicates a trichotomy of proximal (1st person: speaker), medial (2nd person: addressee), and distal (3rd person: other). Since medial pronouns play a crucial role in speech situations (Halliday \& Hasan 1976), the present study considers them as proximal when comparing proximal-distal ratios. ${ }^{6}$ Meanwhile, temporal relations are generally represented by tense forms, modals, and temporal adverbs. In tense forms, the proximal tense includes the simple present, while the distal tense covers the simple past and the past perfect. Although scholars such as Bühler (1934) and Fillmore (1975 [1997]) do not consider modals as part of deictic systems, the present study regards modals as belonging to the spatiotemporal systems. The speakers locate the situation including a modal on a time axis, judging how distant it is from their domain (Brisard 2002; Halliday \& Matthiessen

5 Table 1 covers major spatio-temporal elements. Elements which are not distinctively proximal or distal (e.g., the present perfect) are excluded from Table 1.

6 I will come back to this point in Section 3, where the ratios of proximal and distal elements are discussed. 
2014). In contrast to Middle English, must has a proximal form only, and the contracted form ' $l l$ is employed in the corpus of Early Modern English. When analysing the systems, the present research will concentrate on the proximal-distal distinction and will not go into the details of metaphorically extended meanings.

Thirdly, one might consider spatio-temporal systems as a mere accumulation of the spatial and temporal systems; rather, these systems are interrelated such that they constitute an integrated system. The proximal or distal elements may coordinate only in the spatial or temporal domain, or in the integrated spatiotemporal domain. If a proximal perspective is taken, proximal elements of both space and time may appear together in discourse. Likewise, when a distal perspective is assumed, distal spatial elements may coexist with distal temporal elements. What is important here is that the speakers may keep the same perspective, or even alternate different perspectives in their discourse. To summarise, this definition makes a systematic analysis of the systems possible.

\section{Proximal and distal perspectives}

\subsection{Frequency analysis}

Having provided a definition of spatio-temporal systems, this section will carry out a quantitative analysis of the spatio-temporal elements regarding which perspective, proximal or distal, is likely to be taken. First, Table 2 presents the frequencies of elements which belong to the spatio-temporal systems in Julius Caesar. Normalised frequencies per 10,000 words are given for each element:

Table 2. Frequency of spatio-temporal elements

\begin{tabular}{llrr}
\hline Category & \multicolumn{1}{c}{$\begin{array}{c}\text { Spatio-temporal } \\
\text { element }\end{array}$} & Actual count & /10,000 words \\
\hline Pronoun & 1st person & 1,195 & 577.0 \\
& 2nd person & 792 & 382.4 \\
& th-form & 217 & 104.8 \\
& $y$-form & 575 & 277.6 \\
& 3rd person & 955 & 461.1 \\
& Total & 2,942 & $1,420.6$ \\
\hline Demonstrative & this/these & 203 & 98.0 \\
& that/those & 61 & 29.5 \\
& Total & 264 & 127.5 \\
\hline
\end{tabular}




\begin{tabular}{|c|c|c|c|}
\hline \multirow[t]{5}{*}{ Adverb (spatial) } & here & 65 & 31.4 \\
\hline & there & 21 & 10.1 \\
\hline & existential there & 34 & 16.4 \\
\hline & Other & 21 & 10.1 \\
\hline & Total & 141 & 68.1 \\
\hline \multirow[t]{6}{*}{ Tense form } & simple present & 1,171 & 565.4 \\
\hline & simple past & 429 & 207.1 \\
\hline & present perfect & 145 & 70.0 \\
\hline & past perfect & 8 & 3.9 \\
\hline & other & 6 & 2.9 \\
\hline & Total & 1,759 & 849.3 \\
\hline \multirow[t]{12}{*}{ Modal } & shall & 129 & 62.3 \\
\hline & will & 141 & 68.1 \\
\hline & can & 27 & 13.0 \\
\hline & may & 39 & 18.8 \\
\hline & must & 38 & 18.3 \\
\hline & 'll & 33 & 15.9 \\
\hline & should & 43 & 20.8 \\
\hline & would & 42 & 20.3 \\
\hline & could & 18 & 8.7 \\
\hline & might & 10 & 4.8 \\
\hline & other & 14 & 6.8 \\
\hline & Total & 534 & 257.8 \\
\hline \multirow[t]{4}{*}{ Adverb (temporal) } & now & 65 & 31.4 \\
\hline & then & 58 & 28.0 \\
\hline & other & 0 & 0.0 \\
\hline & Total & 123 & 59.4 \\
\hline
\end{tabular}

The discussion starts with the spatial domain. Of all pronouns, the 1st person pronouns are used most frequently, followed by the 3rd person pronouns. The frequency of the 1st person and the 2nd person pronouns are higher than other types of speech-related texts (Culpeper \& Kytö 2000: 184-185), ${ }^{7}$ which seems to stem

7 Culpeper \& Kytö (2000: 184-185) analysed four types of speech-related texts in The Corpus of Dialogues (1600-1720): witness depositions, trial proceedings, and prose fictions in addition to drama (comedies). When compared with the former three texts, the high frequency of the 1st person and the 2nd person pronouns are conspicuous in drama (comedies), as well as in Julius Caesar, as is shown in Table (i): 
from the fact that most of the corpus is written in the form of dialogue. In dialogues, dramatic dialogues in particular, the speakers often refer to themselves with 1st person pronouns, and talk to the addressees with 2 nd person pronouns. As regards the 2nd person pronouns, i.e., th-forms (thou, thee, thy, thine) and $y$-forms (ye, you, your, yourself, and yours) (Walker 2007: 1), y-forms are employed more frequently. The proximal demonstratives this/these are used far more often than the distal demonstratives that/those. The speakers are more likely to point to their own, proximal domain. Likewise, spatial adverbs have a tendency for proximals.

Turning to the elements of time, temporal relations are mostly represented by tense forms, the simple present and the simple past in particular. The simple present is exploited most often, ${ }^{8}$ which naturally derives from the characteristics of dialogues. On the other hand, the simple past is used less often than the simple present, and the past perfect appears in a very limited number. A wide variety of modals are used in the corpus, and among those modals, shall and will and their distal forms should and would are employed more often than other modals. By Shakespeare's time, shall and will had acquired the meaning and function close to the future tense (Nakayasu 2009), which seems to contribute to this high frequency. In the corpus, only the proximal form of the modal must is recorded, and a significant number of contracted forms ' $l l$ are employed, both of which are characteristics of Early Modern English. The temporal adverb now is used slightly more frequently than then.

\subsection{Proximal and distal elements}

Now that the frequency of each spatio-temporal element has been confirmed, the next step is to examine which perspective, proximal or distal, is likely to be taken in Julius Caesar. Figures 1-4 show the results of frequency analysis of the elements included in Table 2, with a contrast between proximal and distal. Here only elements which are obviously proximal or distal are included in the analysis.

\begin{tabular}{l|c|c|c|c|c}
\hline \multicolumn{2}{c}{ Table (i). Frequency of 1st- and 2nd-person pronouns } \\
\hline & $\begin{array}{c}\text { Witness } \\
\text { depositions }\end{array}$ & $\begin{array}{c}\text { Trial } \\
\text { proceedings }\end{array}$ & $\begin{array}{c}\text { Prose } \\
\text { fiction }\end{array}$ & $\begin{array}{c}\text { Drama } \\
\text { (comedies) }\end{array}$ & $\begin{array}{c}\text { Julius } \\
\text { Caesar }\end{array}$ \\
\hline 1st person & 105.5 & 578.9 & 371.8 & 643.8 & 577.0 \\
\hline 2nd person & 62.9 & 297.3 & 210.8 & 443.0 & 382.4 \\
\hline
\end{tabular}

In Table (i), the data of witness depositions, trial proceedings, prose fiction, and drama (comedies) are adopted from Culpeper \& Kytö (2000: 184-185) and normalised to 10,000 words (following Nevalainen (2002: 208-209)), and those from Julius Caesar are mine. See also Busse (2002) for a comprehensive analysis of 2nd person pronouns in Shakespeare.

8 No historical present is recorded in the corpus. 
Starting the discussion with the spatial domain, Figure 1 represents the relative percentage share of the pronouns employed in the corpus, in terms of the distance from the speaker's domain:

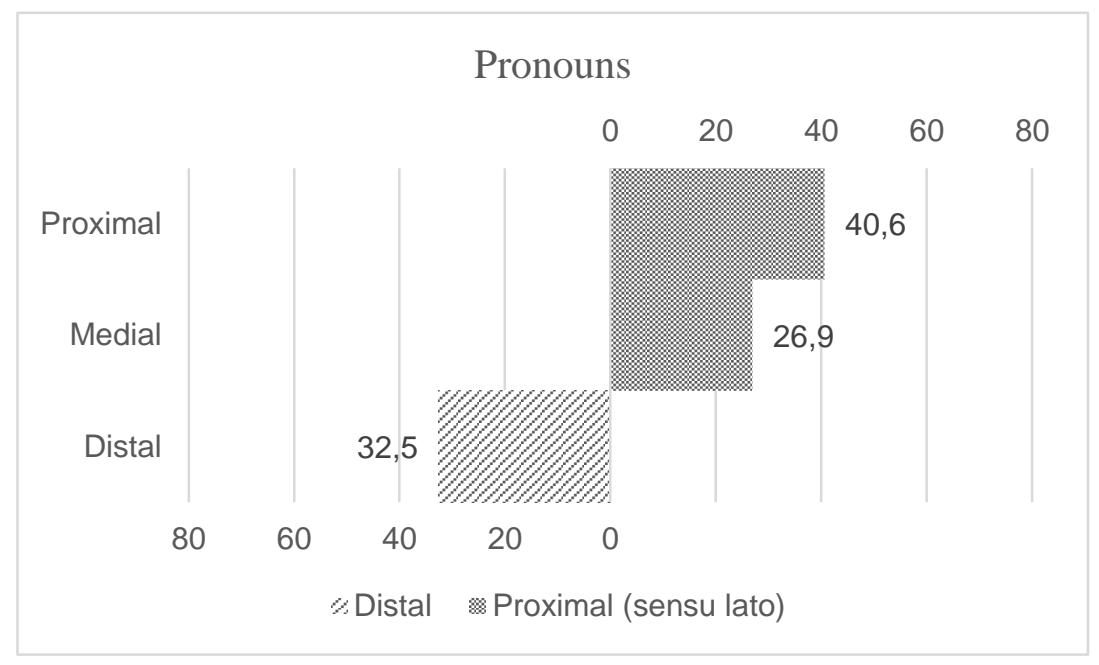

Figure 1. Pronouns

As seen in Section 2, pronouns display a trichotomy of proximal, medial, and distal pronouns. In Figure 1 above, the medial pronouns are given a position in the proximal domain along with the proximal pronouns proper. This is in line with Halliday \& Hasan (1976: 45), who argue that the person system derives its significance from the person's (or object's) relevance to the speech situation: that is to say, they consider the roles of speaker and the addressee as different from other roles. ${ }^{9}$ Pronouns sensu stricto $(40.6 \%)$ already take up a higher share than other pronouns, and if pronouns sensu lato (i.e., proximal and medial pronouns altogether) are taken into consideration, the share will be even higher (67.5\%). The characteristics of dialogues, where the speaker and the addressee interact with each other using these pronouns, have a notable effect on this high share.

Figure 2 represents the ratios of demonstratives and spatial adverbs in a similar pattern:

\footnotetext{
${ }^{9}$ See also Diessel (1999: 39) and Huang (2014: 195-197).
} 


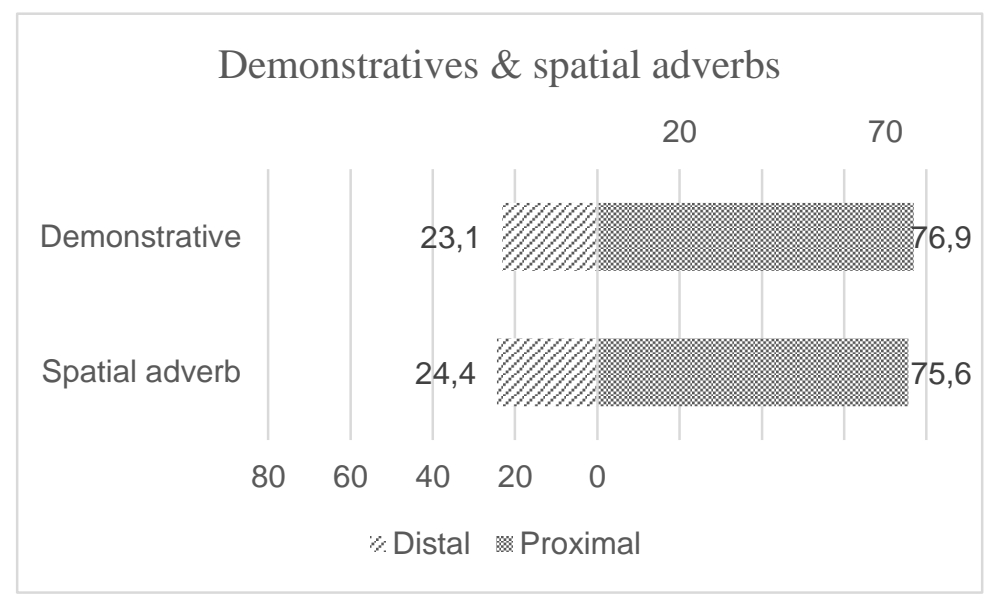

Figure 2. Demonstratives and spatial adverbs

Both demonstratives and spatial adverbs display a strong tendency towards proximal: even if the existential there is included in the category of there, proximal forms still prevail (54.2\%): the speakers often refer to the entities and places in their own domain.

The proximal-distal ratios of the elements in the temporal domain are represented in Figure 3 below:

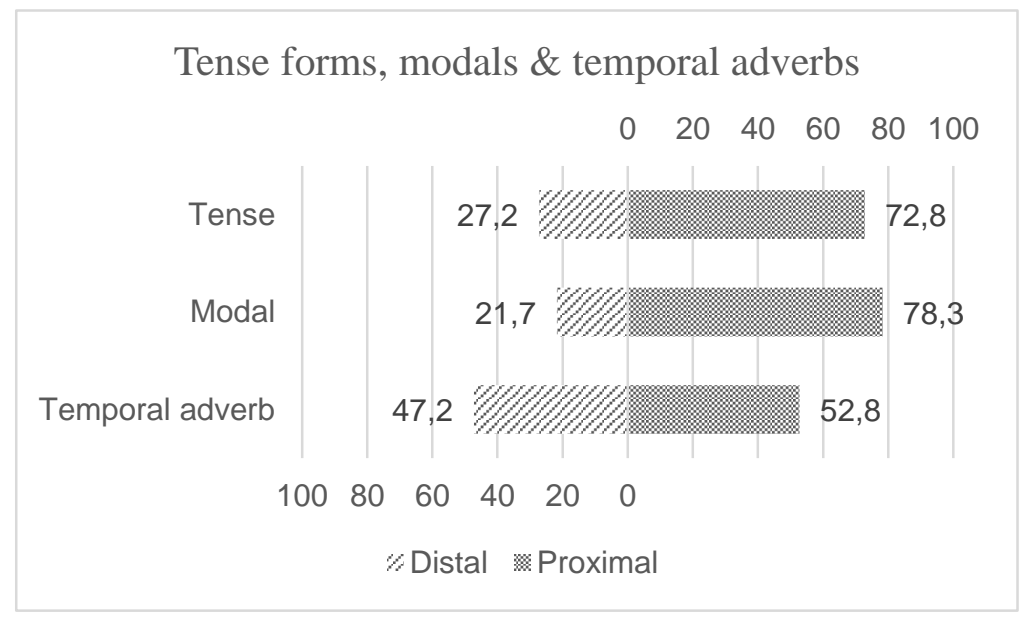

Figure 3. Tense forms, modals and temporal adverbs

In the categories of the tense and the modal, proximal forms take up a higher share than distal ones, the modal in particular. This reflects the modal's direct connection to the speaker's domain in dialogues, and the proximal modals include 
a certain number of instances with the meaning and function close to the future tense. The proximal-distal ratio of the temporal adverb is close to fifty-fifty, with a slight tendency towards proximal.

Figure 4 summarises the results of the preceding analysis of all the major spatio-temporal elements employed in the corpus, by showing which perspective, proximal or distal, is likely to be taken:

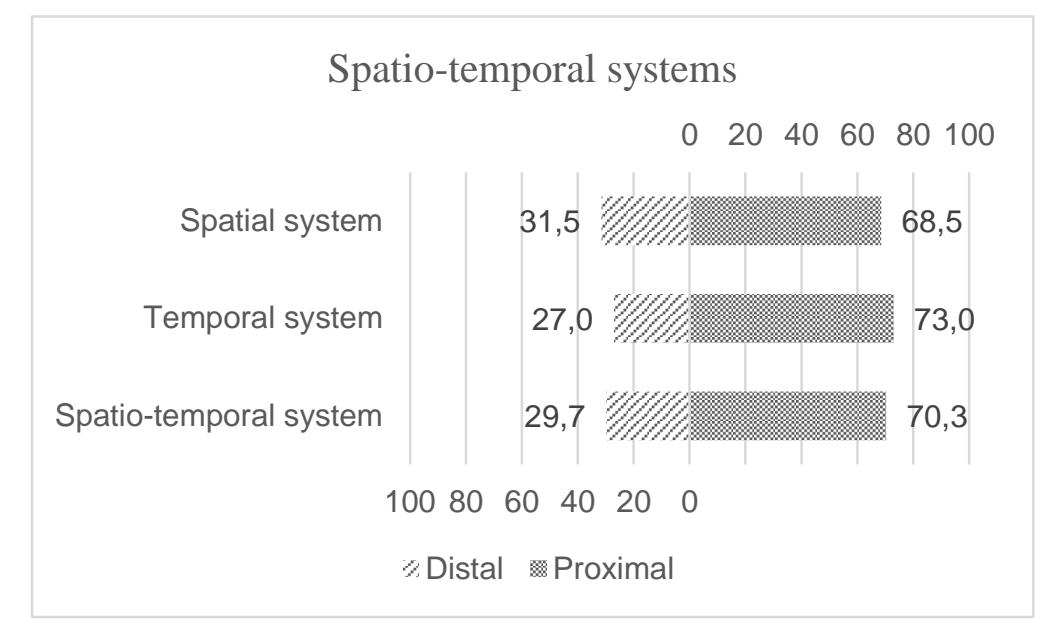

Figure 4. Spatio-temporal systems

It is clear from Figure 4 that the proximal perspective is more likely to be taken in Julius Caesar, and this tendency is stronger in the temporal system. Since most of this corpus is written in the form of dialogue, the speakers often refer to their own and their addressees' domains.

\subsection{Proximal and distal elements and major characters}

Before proceeding to the qualitative analysis, I will examine how the main characters of this play utilise spatio-temporal systems.

Figure 5 compares the spatial and temporal systems adopted by male characters, that is, Caesar (triumvir), Brutus (conspirator) and Antony (Caesar's friend): 


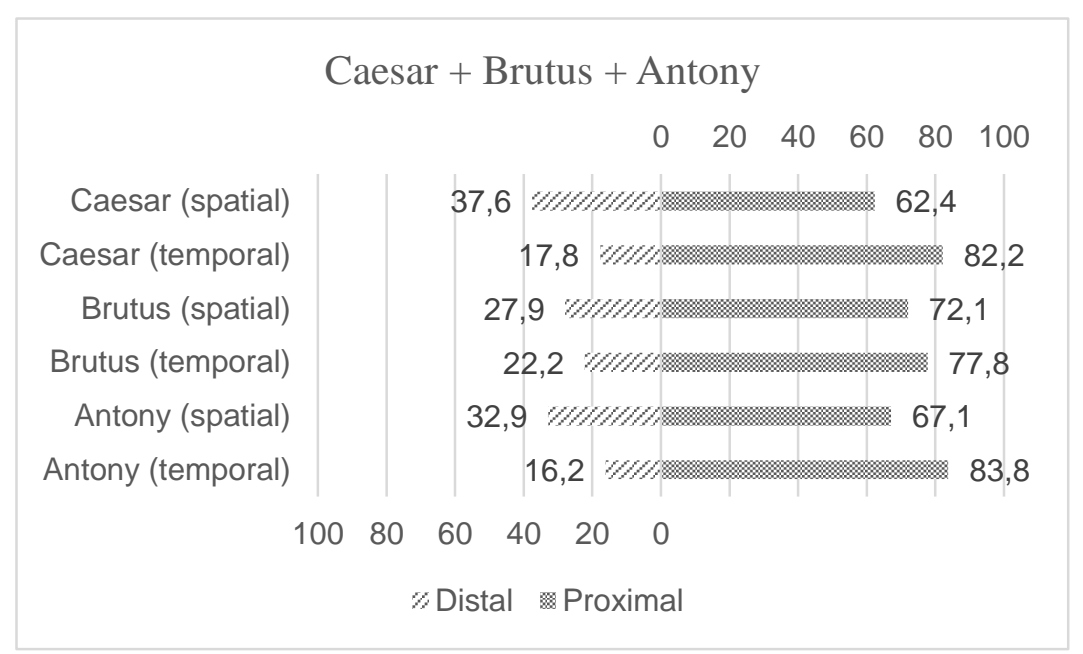

Figure 5. Caesar, Brutus, and Antony

As seen already in the discussion so far, the ratios of proximal elements are higher in general. Regarding all three characters, the proximal temporal elements take the higher share than proximal spatial elements. Among them, Caesar's proximaldistal ratio in the spatial domain leans more towards distal than the other two characters. This is mainly due to the fact that he does not employ demonstratives and spatial adverbs to refer to entities and places very often, while Brutus and Antony employ them more frequently, particularly proximal ones.

The spatio-temporal systems exploited by female characters, Calphurnia (Caesar's wife) and Portia (Brutus' wife), are presented in Figure 6:

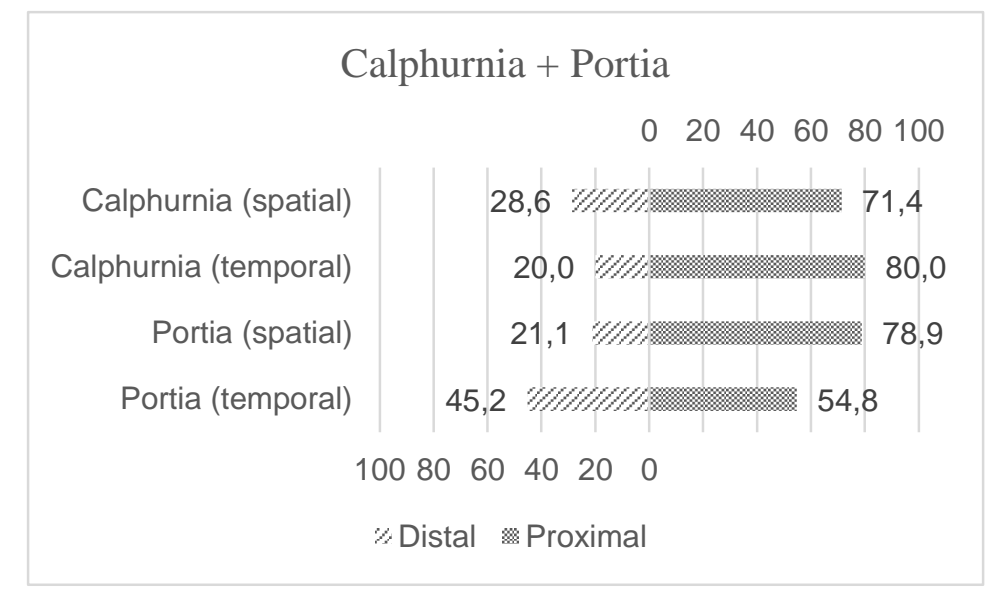

Figure 6. Calphurnia and Portia 
It should be noted that the ratio of Calphurnia's proximal temporal elements is much higher than Portia's. This is mainly due to their different strategies of persuading their husbands utilising modals. Calphurnia tries to persuade Caesar not to go out using proximal modals only, appealing to him more directly (Nakayasu 2014: 20). Portia, by contrast, attempts to persuade Brutus to let her know of his secrets by employing distal modals more often, distancing herself from the direct speech act.

Figure 7 below summarises the ratio between proximal and distal elements employed by the main male and female characters:

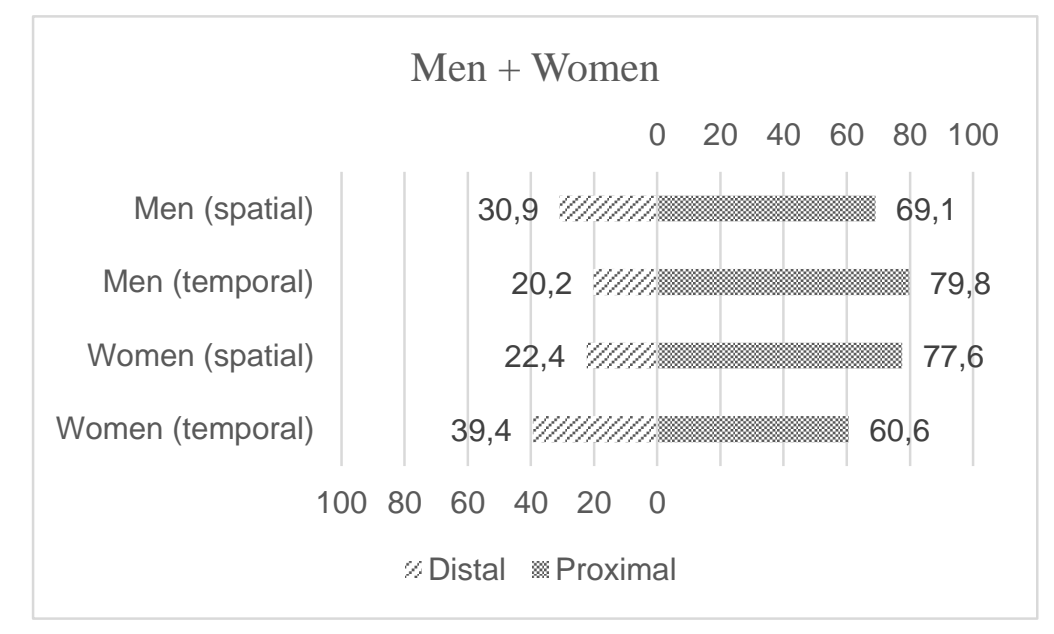

Figure 7. Men and women

In general, they use proximal elements more frequently than distal elements, as already seen in 3.2. Women employ proximal elements slightly more frequently than men in the spatial domain. In the temporal domain, however, women have a stronger tendency towards distal perspective than men.

\section{Spatio-temporal systems in dialogue/discourse}

\subsection{Discourse structuring}

Having conducted a quantitative analysis of the elements of space and time and confirmed that the characteristics of dialogues promote a proximal perspective in the corpus, this section will carry out a qualitative analysis, exploring further into dialogue and discourse. I will first examine micro-level aspects of discourse, and 
then proceed to a macro-level analysis to observe how proximal and distal perspectives are evoked and how these perspectives shift in dialogue and discourse.

The discussion starts with elements which structure discourse in spatiotemporal systems: e.g., metadiscoursal expressions, discourse markers, and textdeictic expressions. Metadiscourse is defined as "comprising all those elements in a text which do not add new material to the text proposition, but which are used to refer to already existing text-propositional elements" (Boggel 2009: 2). Since metadiscourse is directly connected to the speaker's domain, it can be used to emphasize certain elements in the text and reveals how the speaker is trying to interact with the addressee. In (2) below, where the speaker, Antony, is trying to persuade the Roman citizens against Brutus, as you know functions as metadiscourse:

(2) Ant. [...] See what a rent the envious Casca made; Through this the well-beloved Brutus stabb'd, And as he pluck'd his cursed steel away, Mark how the blood of Caesar followed it, As rushing out of doors to be resolv'd If Brutus so unkindly knock'd or no; For Brutus, as you know, was Caesar's angel. Judge, O you gods, how dearly Caesar lov'd him! This was the most unkindest cut of all; [...]

(JC 3.2.175-183)

Note that the metadiscoursal expression includes the medial pronoun you (proximal sensu lato) and a proximal tense form, although most other elements are distal. This means that the speaker selects spatio-temporal elements for metadiscourse independently from the other part of the text. Other metadiscoursal expressions include: I mean (JC 3.1.42), I say (JC 3.3.16), and as I told you (JC 1.2.238). As the last example shows, not only proximal tense forms but also distal ones are possible. It should be noted that these metadiscoursal expressions used in dialogues are generally interactional, i.e., referring to the information shared by both interlocutors (e.g., as you know and as I told you), and intensifying or modifying the speech act (e.g., I say and I mean).

Some spatio-temporal elements can be used as discourse markers (Schiffrin 1987; Brinton 2017) ${ }^{10}$ and text-deictic expressions (Fries 1994). In this case, their prototypical meaning and function are extended to acquire new ones. Temporal adverbs now and then can be used as discourse markers. In example (3), Cassius

10 Brinton (2017) employs the term pragmatic marker. 
attempts to persuade Casca into the conspiracy to assassinate Caesar. When the bargain is made (i.e., Casca agrees), Cassius employs the temporal adverb now to change the topic to other conspirators:

(3) Casca. You speak to Casca, and to such a man That is no fleering tell-tale. Hold, my hand. Be factious for redress of all these griefs, And I will set this foot of mine as far As who goes furthest.

Cas. There's a bargain made. Now know you, Casca, I have mov'd already Some certain of the noblest-minded Romans To undergo with me an enterprise Of honorable-dangerous consequence; [...]

(JC 1.3.116-124)

In this dialogue, now has a strong connection to the speaker's domain, and introduces a metacomment as a discourse-structuring device (Taavitsainen \& Hiltunen 2012: 181-184). The use of this discourse marker is supported by other proximal and medial elements such as know you.

The temporal adverb then is employed twice in (4) below, where Brutus asks Casca what happened to Caesar on that day:

(4) Casca. You pull'd me by the cloak, would you speak with me?

Bru. Ay, Casca, tell us what hath chanc'd to-day

That Caesar looks so sad.

Casca. Why, you were with him, were you not?

Bru. I should not then ask Casca what had chanc'd.

Casca. Why, there was a crown offer'd him; and

being offer'd him, he put it by with the back of his

hand thus, and then the people fell a-shouting.

Bru. What was the second noise for?

Casca. Why, for that too.

(JC 1.2.215-225)

In this dialogue, Brutus uses the first then, reacting to his interlocutor Casca, and explains the reason why he asks that question. The second then represents the order of events and what happened next (Nakayasu 2019: 127-128).

The most typical text-deictic element found in the corpus is the demonstrative this, whose prototypical meaning is pointing to an entity close to the speaker in the spatial or the temporal domain. The context in (5), where Brutus and Cassius are having a quarrel, exemplifies the use of anaphoric this: 
(5) Bru. Away, slight man!

Cas. Is't possible?

Bru. $\quad$ Hear me, for I will speak.

Must I give way and room to your rash choler?

Shall I be frighted when a madman stares?

Cas. O ye gods, ye gods, must I endure all this?

Bru. All this? ay, more. Fret till your proud heart break; [...]

In their dialogue, Cassius refers back to the rude things Brutus has said to him with the anaphoric this. Brutus, exploiting this he used, strikes back. This dialogue exemplifies how skillfully speakers employ spatio-temporal elements in interaction. Cataphoric this, on the other hand, anticipates what will be mentioned later in context (Gernsbacher \& Schroyer 1989). In (6), the speaker, Antony, is trying to persuade Roman citizens against the conspirator Brutus in a public speech:

(6) Ant. [...] But here's a parchment with the seal of Caesar, I found it in his closet, 'tis his will.

Let but the commons hear this testament Which, pardon me, I do not mean to read And they would go and kiss dead Caesar's wounds, And dip their napkins in his sacred blood; Yea, beg a hair of him for memory, And dying, mention it within their wills, Bequeathing it as a rich legacy Unto their issue.

He has Caesar's will, and intentionally refers to the contents of the will in advance using the cataphoric this. His aim to get the Roman citizens interested in it and persuade them against Brutus will be successful later.

\subsection{Proximal and distal perspectives}

This subsection will go further into a macro-level analysis to examine how proximal or distal elements from both spatial and temporal domains are coordinated to take either a proximal or distal perspective, and how these perspectives alternate in discourse.

Our first example provides a starting point to examine such coordination to take a proximal perspective. In (7) below, Brutus invites his friends in his camp: 
(7) Enter TITINIUS and MESSALA.

Bru. Come in, Titinius. Welcome, good Messala.

Now sit we close about this taper here,

And call in question our necessities.

Cas. Portia, art thou gone?

Bru. $\quad$ No more, I pray you.

(JC 4.3.163-166)

In Brutus' first turn, all the spatio-temporal elements belonging to both spatial and temporal domains are proximal: a pronoun, a demonstrative, the adverbs here and now, and tense forms. He also employs the imperative come in, the interjection welcome, and the forms of address Titinius and good Messala, which support the proximal perspective. Cassius, addressing Portia (Brutus' wife and now dead), employs the medial pronoun and the proximal tense in the form of question. Brutus then utters I pray you, which also promotes a proximal perspective. This example illustrates clearly that the interlocutors keep their perspective proximal in their dialogue. In the next example (8), Brutus addresses his servant boy Lucius, who is sleeping:

(8) Bru. [...] This is a sleepy tune. O murd'rous slumber!

Layest thou thy leaden mace upon my boy, That plays thee music? Gentle knave, good night; I will not do thee so much wrong to wake thee. If thou dost nod, thou break'st thy instrument, I'll take it from thee; and, good boy, good night. Let me see, let me see; is not the leaf turn'd down Where I left reading? Here it is, I think.

(JC 4.3.267-274)

In a similar way to (7), he employs proximal and medial pronouns, the proximal demonstrative this, the proximal adverb here, proximal tense forms, and proximal modals. The forms of address gentle knave and good boy reinforce this proximal perspective. It is worth noting here that the medial pronouns are all th-forms, which denote intimacy that Brutus holds for Lucius. ${ }^{11}$ Recall also that Brutus and Cassius, having a quarrel with each other in (5), employ a variety of proximal elements in addition to the proximal demonstrative this, which is used as a textdeictic element: proximal and medial pronouns, proximal tense forms, and proximal modals. This proximal perspective is backed up by the imperative Hear me and the questions Must I give way and rooms to your rash choler? and Shall

11 Busse (2002: 171) notes that knave, if preceded by a positive adjective such as good, gentle and pretty, is used together with an intimate thou from the superior. 
I be frighted when a madman stares?. In (9), where Cassius is trying to persuade Brutus to join the conspiracy, Brutus employs the deictic verb come twice, in addition to various proximal elements:

(9) Bru. And so it is. For this time I will leave you;

To-morrow, if you please to speak with me,

I will come home to you; or, if you will,

Come home to me, and I will wait for you.

Cas. I will do so; till then, think of the world.

Exit Brutus.

Well, Brutus, thou art noble; [...]

(JC 1.2.303-308)

Cassius replies to him, I will do so, which means 'I will come home to you'. They use come home to you/me (and do so) to approach each other's domain. ${ }^{12}$ This strategy can be considered to support the proximal perspective they take in their dialogue.

The coordination of distal elements from both spatial and temporal domains to take a distal perspective can be observed: although there are ample examples where a proximal perspective is evoked and numerous strategies supporting proximal perspectives are employed, instances of distal perspectives in discourse are less easy to find..$^{13}$ In (10), Casca informs Brutus and Cassius of what he observed about Caesar (=(4), repeated here for the sake of convenience):

(10) Casca. You pull'd me by the cloak, would you speak with me?

Bru. Ay, Casca, tell us what hath chanc'd to-day That Caesar looks so sad.

Casca. Why, you were with him, were you not?

Bru. I should not then ask Casca what had chanc'd.

Casca. Why, there was a crown offer' $\mathrm{d}$ him; and

being offer'd him, he put it by with the back of his hand thus, and then the people fell a-shouting.

Bru. What was the second noise for?

Casca. Why, for that too.

(JC 1.2.215-225)

12 This and other examples in this subsection where a proximal perspective is evoked can be analysed with the theory of politeness (cf. Brown \& Levinson 1987; Brown \& Gilman 1989; Kopytko 1993). I will not pursue this issue in this short paper.

13 This characteristic is different from that used in fiction, where distal perspectives can be taken more frequently. See Nakayasu $(2018 ; 2019)$ for an analysis of the fiction The Canterbury Tales, although the time period of this work is Middle English. 
Casca and Brutus (in his second turn) successively employ distal elements: distal pronouns, the distal demonstrative that, distal tense forms, distal modals, and distal adverbs. It is clear from this example that reporting and discussing what happened in the past can promote a distal perspective, and that the interlocutors can cooperate with each other to keep the perspective distal in their dialogue. As already seen in the discussion of (4), the adverb then is used twice as a discourse marker. The following context (11) comes from a later context in the same scene, where a distal perspective is taken:

(11) Casca. [...] I saw Mark

Antony offer him a crown - yet 'twas not a crown neither, 'twas one of these coronets - and as I told you, he put it by once; but for all that, to my thinking, he would fain have had it. Then he offer'd it to him again; then he put it by again; but, to my thinking, he was very loath to lay his fingers off it. And then he offer'd it the third time; he put it the third time by; [...]

(JC 1.2.236-243)

The speaker Casca utilises distal pronouns, the demonstrative that, tense forms, the adverb then and the pattern "modal + perfect infinitive" to report what happened in the past. As seen earlier in the discussion of metadiscourse in the present section, the expression as I told you functions as metadiscourse. Though this expression is apart from the distal contents of what happened in the past, it signifies a distal point in the past viewed from the speaker's domain.

\subsection{Alternation between proximal and distal perspectives}

So far we have seen how proximal or distal elements are combined to evoke a proximal or distal perspective. Once a proximal or distal perspective is set up, the speakers can keep the same perspective, or alternate different perspectives in the dialogue and discourse. This final subsection will examine the alternation between proximal and distal perspectives in discourse. This can happen in either the spatial or the temporal domain, as well as in an integrated spatio-temporal domain.

First, the alternation between perspectives may occur only in the spatial domain. ${ }^{14}$ In (12), Brutus discusses strategies with Cassius to defeat their enemy:

(12) Bru. Good reasons must of force give place to better:

The people 'twixt Philippi and this ground

Do stand but in a forc'd affection,

14 The perspective alternation only in the spatial domain is found in a limited number of contexts. 
For they have grudg'd us contribution. The enemy, marching along by them, By them shall make a fuller number up, Come on refresh'd, new-added, and encourag'd; From which advantage shall we cut him off If at Philippi we do face him there, These people at our back.

Although the elements in the temporal domain remain proximal (except for one present perfect instance, which is neither proximal or distal), those in the spatial domain go to and from proximal and distal. Starting from the proximal (this ground: where we are), the perspective shifts through distal (they/them: people), proximal (we), distal (him: enemy; there: Phillipi), and finally to proximal (these people; our back).

Second, the alternation in perspectives may occur only in the temporal domain. For example, Antony gives a public speech trying to persuade the Roman citizens against Brutus in (13):

(13) Ant. If you have tears, prepare to shed them now. You all do know this mantle. I remember The first time ever Caesar put it on; [...] Look, in this place ran Cassius' dagger through; [...] Through this the well-beloved Brutus stabb'd, [...] For Brutus, as you know, was Caesar's angel. Judge, O you gods, how dearly Caesar lov'd him! This was the most unkindest cut of all; [...]

We can observe his skillful strategies to direct the citizens' attention to both proximal and distal temporal domains. He starts with proximal tense forms with the aid of the proximal adverb now and the proximal demonstrative this, addressing directly to their feelings. He then switches to distal tense forms to refer to what happened to Caesar, with continuing help from this. This particular use of the proximal demonstrative this has the function of always bringing the citizens' attention back to Caesar's mantle and the cut made there in front of their eyes. As examined in (2), as you know is a metadiscoursal expression.

In (14), Brutus and Cassius are still having a quarrel in a later context of (5):

(14) Cas. Is it come to this?

Bru. You say you are a better soldier:

Let it appear so; make your vaunting true, 
And it shall please me well. For mine own part, I shall be glad to learn of noble men.

Cas. You wrong me every way; you wrong me, Brutus:

I said an elder soldier, not a better:

Did I say "better"?

Bru. If you did, I care not.

(JC 4.3.50-57)

In this dialogue, the alternation from proximal to distal perspective in the temporal domain can be observed, while the spatial domain is kept proximal (and medial). After Cassius complains to Brutus referring to what he has said with the anaphoric this, Brutus criticises Cassius with the aid of you say for saying he is a better soldier. This encourages them to keep the perspective proximal. Then Cassius switches the perspective to distal, speaking out against Brutus with I said, and correcting what he said. From this particular point, they start employing distal temporal elements. This example vividly illustrates how spatio-temporal systems work in dialogue.

Third, the proximal and distal perspectives may alternate in the integrated spatio-temporal domain. In (15), Brutus and Cassius are talking before the final fight on Cassius' birthday:

(15) Cas. Then, if we lose this battle, You are contented to be led in triumph Thorough the streets of Rome?

Bru. No, Cassius, no. Think not, thou noble Roman, That ever Brutus will go bound to Rome;

He bears too great a mind. But this same day

Must end that work the ides of March begun.

(JC 5.1.107-113)

The point to observe is that the alternation in the integrated spatio-temporal domain occurs in the bottom two lines. Brutus selects the proximal demonstrative this and the proximal modal must, and then switches to the distal demonstrative that and the distal tense form begun, contrasting the two days, i.e., the day when he is confronting the final fight and the ides of March when he assassinated Caesar. The example (16) below (the same as (1), repeated here for convenience) also represents a clear contrast between two perspectives. The speaker, Antony, in his public speech to persuade the citizens against Brutus, takes a distal perspective when he refers to Caesar, while assuming a proximal perspective when he mentions Brutus: 
(16) Ant. [...] Did this in Caesar seem ambitious? [...]

Yet Brutus says he was ambitious,

And Brutus is an honorable man.

You all did see that on the Lupercal

I thrice presented him a kingly crown,

Which he did thrice refuse. Was this ambition?

Yet Brutus says he was ambitious,

And sure he is an honorable man.

(JC 3.2.90-99)

He employs distal pronouns, distal tense forms, and the distal demonstrative that for Caesar, whereas he resorts to proximal tense forms for Brutus. What should be borne in mind is that he skillfully exploits these strategies to approach directly the addressee's feelings: the combination of the proximal demonstrative this in a similar fashion as (13) and rhetorical questions Did this in Caesar seems ambitious? and Was this ambition? A marked contrast between the past and the present of the same person, Caesar, can be observed in (17). Cassius, trying to persuade Brutus into conspiracy, speaks ill of Caesar:

(17) Cas. [...] But ere we could arrive the point propos'd, Caesar cried, "Help me, Cassius, or I sink!"

[...] And this man

Is now become a god, and Cassius is

A wretched creature, [...].

He had a fever when he was in Spain,

And when the fit was on him, I did mark

How he did shake - 'tis true, this god did shake;

His coward lips did from their color fly,

And that same eye whose bend doth awe the world

Did lose his lustre; I did hear him groan; [...]

(JC 1.2.110-124)

The speaker, Cassius, uses distal pronouns, distal tense forms, a distal modal, and the demonstrative that (combined with same) to describe Caesar in the past. For the present situation concerning Caesar and Cassius himself, by contrast, he employs proximal tense forms (and the present perfect), the proximal demonstrative this, and the adverb now.

Finally, a more complex phenomenon regarding perspective shifts can be observed in Julius Caesar. Intriguingly, the alternation in both domains can cross with each other: that is to say, the perspective is proximal in the spatial domain while distal in the temporal domain, and when the perspectives alternate, the perspective shifts to distal in the spatial domain whereas proximal in the temporal 
domain; or vice versa. However, no such examples have so far been recorded in the corpora of Middle English; but a larger corpus would be needed to obtain definitive results.

The first and most characteristic example to illustrate this phenomenon is (18), where Titinius and Messala are talking about Cassius, who is dead:

(18) Tit. These tidings will well comfort Cassius. Mes. Where did you leave him?

Tit. All disconsolate,

With Pindarus his bondman, on this hill.

Mes. Is not that he that lies upon the ground?

Tit. He lies not like the living. O my heart!

Mes. Is not that he?

Tit. No, this was he, Messala,

But Cassius is no more. O setting sun, $[\ldots]$

(JC 5.3. 54-60)

Messala utters Is not that he?, pointing to Cassius' body. He employs a proximal tense form and the distal demonstrative that. Replying to his question, Titinius says No, this was he, switching to the distal tense form and the proximal demonstrative that. Here an alternation crossing the spatial and temporal domains occurs at the same time in dialogue. In fact, a similar, but more complex example occurs in the previous context of (18). On his birthday, Cassius realised that he has lost the fight:

(19) Cas. Go, Pindarus, get higher on that hill; My sight was ever thick; regard Titinius, And tell me what thou not'st about the field. [Pindarus goes up.]

This day I breathed first: time is come round, And where I did begin, there shall I end; My life is run his compass. Sirrah, what news?

(JC 5.3.20-25)

He employs the proximal demonstrative this (i.e., his birthday) and distal tense forms. He then triggers a cross alternation between the spatial and temporal domains, making use of the distal adverb there and the proximal modal shall. Later in context, he dies and Titinius and Messala find his body in (18).

Our final example highlights a cross alternation relevant to the 2nd person pronouns. After Caesar has been assassinated, Antony comes to the Capitol, and talks to the conspirators and then to Caesar's body: 
(20) Ant. I doubt not of your wisdom.

Let each man render me his bloody hand.

First, Marcus Brutus, will I shake with you; [...]

Gentlemen all - alas, what shall I say?

My credit now stands on such slippery ground [...]

That I did love thee, Caesar, O, 'tis true; [...]

Pardon me, Julius! Here wast thou bay'd, brave hart,

Here didst thou fall, and here thy hunters stand,

Sign'd in thy spoil, and crimson'd in thy lethe.

(JC 3.1.183-206)

He addresses the conspirators using proximal tense forms and proximal modals with the aid of forms of address. He then turns to Caesar's dead body and employs a distal tense form and the form of address Caesar. After the conspirators have left, he addresses Caesar, using distal tense forms and the form of address Julius, which this time is his first name to show intimacy. ${ }^{15}$ Interestingly enough, he takes a proximal perspective but uses $y$-forms of the 2 nd person pronoun when talking to the conspirators; when he addresses Caesar, by contrast, he assumes a distal perspective but employs th-forms of the 2 nd person pronoun. Because thforms are used when the speaker with superior power talks to the addressee with a close relationship (Walker 2007: 292), it can be safely said that a cross alternation occurs in this example. These examples clearly illustrate how the speakers manage the spatio-temporal elements and the proximal and distal perspectives in dialogue and discourse.

\section{Concluding remarks}

This paper has conducted a systematic analysis of the spatio-temporal systems in Shakespeare's dialogues against the background of historical pragmatics and discourse analysis. Focusing on Julius Caesar, the present paper conducted a quantitative and qualitative analysis of the systems of space and time. A quantitative analysis of each spatio-temporal element and the proximal-distal ratios demonstrated that the proximal perspective is more likely to be taken in the corpus, which derives from the characteristics of dialogues. And a comparison among major male and female characters revealed some differences in employing contrasting strategies.

15 In the classical period, Romans had the tria nomia, or three names system (Hornblower \& Spawforth 2012: 996). Thus, Gaius is the praenomen, Julius is the nomen, and Caesar is the cognomen. Shakespeare treats Julius as his first name here, although it is his family name. 
A qualitative analysis of dialogue and discourse showed how spatio-temporal elements are combined to take either a proximal or distal perspective and how these perspectives shift in discourse. The micro-level analysis revealed the relations between spatio-temporal elements and some discourse structuring devices such as metadiscourse, discourse markers, and text-deictic expressions. The macro-level analysis furthermore showed how proximal or distal elements and other supporting elements can be combined to evoke either proximal or distal perspective, and how these perspectives alternate in discourse, in either spatial or temporal domain, or in the integrated spatio-temporal domain. A more complex alternation crossing both domains can be observed in Julius Caesar.

In conclusion, this research demonstrated how interlocutors exploit spatial and temporal elements to enliven their communicative intentions, and offers an original perspective on the spatio-temporal systems in Early Modern English. There remain further issues yet to be addressed. First, expanding the corpus to other plays and other genres such as comedies may uncover more characteristics of Shakespeare's use of language. In addition, analysing the relationship between the systems and other factors such as politeness may yield promising results. Moreover, comparing the same register in other periods and other registers in the same period will improve clarification of the overall picture of spatio-temporal systems of different space and time. Such investigations into spatio-temporal systems will elucidate these crucial aspects of communication in the past.

\section{ACKNOWLEDGEMENTS}

First of all, my deep gratitude goes to the late Professor Jacek Fisiak for his warm encouragement and his guidance in life and linguistics.

The earlier version of this paper was presented at HEL-P 2017 (The History of the English Language in Poznań 2017 Conference). I would like to thank the audience at the conference and the two anonymous reviewers who offered me insightful comments and suggestions. This research was supported by Grants-inAid for Scientific Research from the Japan Society for the Promotion of Science (JSPS KAKENHI No. 15K02595; No. 18K00642), which I gratefully acknowledge. 


\section{REFERENCES}

Boggel, Sandra. 2009. Metadiscourse in Middle English and Early Modern English religious texts: A corpus-based study. Peter Lang.

Brinton, Laurel J. 2017. The evolution of pragmatic markers in English: Pathways of change. Cambridge University Press. DOI: 10.1017/9781316416013

Brisard, Frank (ed.). 2002. Grounding: The epistemic footing of deixis and reference. Mouton de Gruyter. DOI: 10.1515/9783110899801

Brown, Penelope \& Stephen C. Levinson. 1987. Politeness: Some universals in language usage. Cambridge University Press.

Brown, Roger \& Albert Gilman. 1989. Politeness theory and Shakespeare's four major tragedies. Language in Society 18(2). 159-212. DOI: 10.1017/S0047404500013464

Bühler, Karl. 1934. Sprachtheorie: Die Darstellungsfunktion der Sprache. G. Fischer.

Busse, Ulrich. 2002. Linguistic variation in the Shakespeare corpus: Morpho-syntactic variability of second person pronouns. John Benjamins. DOI: 10.1075/pbns.106

Culpeper, Jonathan \& Merja Kytö. 2000. Data in historical pragmatics: Spoken interaction (re)cast as writing. Journal of Historical Pragmatics 1(2). 175-199. DOI: $10.1075 / \mathrm{jhp} \cdot 1.2 .03 \mathrm{cul}$

Diessel, Holger. 1999. Demonstratives: Form, function, and grammaticalization. John Benjamins. DOI: $10.1075 /$ tsl.42

Evans, G. Blakemore (gen. ed.). 1997. The Riverside Shakespeare (2nd edn.). Houghton Mifflin Company.

Fillmore, Charles J. 1975. Santa Cruz lectures on deixis, 1971. Indiana University Linguistics Club. [Reprinted in Charles J. Fillmore. 1997. Lectures on deixis. CSLI Publications.]

Fries, Udo. 1994. Text deixis in Early Modern English. In Dieter Kastovsky (ed.), Studies in Early Modern English, De Gruyter Mouton. 111-128. DOI: 10.1515/9783110879599.111

Gernsbacher, Morton A. \& Susanne Shroyer. 1989. The cataphoric use of the indefinite this in spoken narratives. Memory \& Cognition 17(5). 536-540. DOI: 10.3758/bf03197076

Halliday, M. A. K. \& Ruqaiya Hasan. 1976. Cohesion in English. Longman.

Halliday, M. A. K. \& Christian M. I. M. Matthiessen. 2014. Halliday's introduction to functional grammar (4th edn.). Routledge.

Hornblower, Simon \& Antony Spawforth (gen. eds.). 2012. The Oxford classical dictionary (4th edn.). Oxford University Press.

Huang, Yan. 2014. Pragmatics (2nd edn.). Oxford University Press.

Kopytko, Roman. 1993. Polite discourse in Shakespeare's English. Wydawnictwo Naukowe Uniwersytetu im. Adama Mickiewicza w Poznaniu.

Levinson, Stephen C. 1983. Pragmatics. Cambridge University Press. DOI: $10.1017 / \mathrm{CBO} 9780511813313$

Magnusson, Lynne. 1999. Shakespeare and social dialogue: Dramatic language and Elizabethan letters. Cambridge University Press. DOI: 10.1017/CBO9780511483745

Magnusson, Lynne. 2001. Dialogue. In Sylvia Adamson, Lynette Hunter \& Lynne Magnusson (eds.), Reading Shakespeare's dramatic language: A guide, Methuen. 130-143.

Morgan, Oliver. 2019. Turn-taking in Shakespeare. Oxford University Press.

Nagucka, Ruta. 2000. The spatial and temporal meanings of before in Middle English. In Irma Taavitsainen, Terttu Nevalainen, Päivi Pahta \& Matti Rissanen (eds.), Placing Middle English in context, De Gruyter Mouton. 329-337. DOI: 10.1515/9783110869514.329

Nakayasu, Minako. 2009. The pragmatics of modals in Shakespeare. Peter Lang. 
Nakayasu, Minako. 2014. Wilt thou be lord of all the world? Modals and persuasion in Shakespeare. Studia Anglica Posnaniensia 49(1). 5-30. DOI: 10.2478/stap-2014-0001

Nakayasu, Minako. 2015. Spatio-temporal systems in A treatise on the Astrolabe. In Juan Camilo Conde-Silvestre \& Javier Calle-Martín (eds.), Approaches to Middle English: Variation, contact and change, Peter Lang. 243-259.

Nakayasu, Minako. 2017a. Spatio-temporal systems in Margaret Paston's letters. In Jacek Fisiak, Magdalena Bator \& Marta Sylwanowicz (eds.), Essays and studies in Middle English, Peter Lang. 121-140.

Nakayasu, Minako. 2017b. Spatio-temporal systems in Paston letters. Studia Neophilologica 89s1. 75-89. DOI: 10.1080/00393274.2017.1317020

Nakayasu, Minako. 2018. Spatio-temporal systems in Chaucer. In Peter Petré, Hubert Cuyckens Hubert \& Frauke D'hoedt (eds.), Sociocultural dimensions of lexis and text in the history of English, John Benjamins. 125-150. DOI: 10.1075/cilt.343.06nak

Nakayasu, Minako. 2019. Spatio-temporal systems in Chaucer's language: A discourse-pragmatic analysis. Linguistics Beyond and Within 5(1). 120-134. DOI: 10.31743/lingbaw.5384

Nevalainen, Terttu. 2002. Women's writing as evidence for linguistic continuity and change in Early Modern English. In Richard Watts \& Peter Trudgill (eds.), Alternative histories of English, Routledge. 191-209.

Oakeshott-Taylor, John. 1984. Factuality, tense, intonation and perspective: Some thoughts on the semantics of 'think'. Lingua 62(4). 289-317. DOI: 10.1016/0024-3841(84)90056-1

Schiffrin, Deborah. 1987. Discourse markers. Cambridge University Press. DOI: $10.1017 / \mathrm{CBO} 9780511611841$

Taavitsainen, Irma. 1999. Personality and styles of affect in the Canterbury Tales. In Geoffrey Lester (ed.), Chaucer in perspective: Middle English essays in honour of Norman Blake, Sheffield Academic Press. 218-234.

Taavitsainen, Irma \& Turo Hiltunen. 2012. Now as a text deictic feature in Late Medieval and Early Modern English medical writing. In Ulrich Busse \& Axel Hübler (eds.), Investigations into the meta-communicative lexicon of English: A contribution to historical pragmatics, John Benjamins. 179-205. DOI: 10.1075/pbns.220.14taa

Taavtisainen, Irma \& Andreas H. Jucker. 2010. Trends and developments in historical pragmatics. In Andreas H. Jucker \& Irma Taavitsainen (eds.), Historical pragmatics, De Gruyter Mouton. 3-30. DOI: 10.1515/9783110214284.1.3

Taavtisainen, Irma \& Andreas H. Jucker. 2015. Twenty years of historical pragmatics: Origins, developments and changing thought styles. Journal of Historical Pragmatics 16(1). 1-24. DOI: $10.1075 / \mathrm{jhp} .16 .1 .01$ taa

Traugott, Elizabeth C. 1974. Explorations in linguistic elaboration: Language change, language acquisition and the genesis of spatio-temporal terms. In John M. Anderson \& Charles Jones (eds.), Historical linguistics. Vol. 1: Syntax, morphology, internal and comparative reconstruction. Proceedings of the First International Conference on Historical Linguistics, Edinburgh, 2nd-7th September 1973, North-Holland Publishing Company. 263-314.

Traugott, Elizabeth C. 1978. On the expression of spatio-temporal relations in language. In Joseph H. Greenberg (ed.), Universals of human language. Vol. 3: Word structure, Stanford University Press. 369-400.

Walker, Terry. 2007. Thou and you in Early Modern English dialogues: Trials, depositions, and drama comedy. John Benjamins. DOI: 10.1075/pbns.158

Yule, George. 1996. Pragmatics. Oxford University Press. 